\title{
The Impact of Covid-19 on Higher Education: A Review on the Moroccan Case
}

\author{
${ }^{1}$ Belhassan Khaoula, ${ }^{2}$ Azegagh Jalal \\ ${ }^{1,2}$ National School of Business and Management, Ibn Tofail university, Morocco
}

\begin{abstract}
The period 1999-2009 was considered as "the decade of education" in Morocco because of the main projects of the overhaul of the education system launched during this period. This period has seen profound reforms which affected the organization, pedagogy, and financial management of Moroccan universities to improve their performances and to offer the market a skilled workforce. In March 2020, Morocco recorded the first positive cases of Covid-19. Following this situation and in interaction with the international circumstances, the country has embarked on an anticipatory strategy to limit the spread of this new virus through confinement that lasted from March 20 to July 10, 2020, influencing the normal functioning of most sectors and disrupting the strategies of all sectors of activity. The higher education sector has not escaped the effects of the pandemic. Through this article, we wonder about the impact of covid-19 on Moroccan higher education, scientific research, and currents project launched in this sector. We found that the learning process in universities was the most negatively impacted by the pandemic, at the same time, the scientific research mission saw improvements in publications and research funding during the crisis. Finally, the article highlights lessons from this pandemic for the Moroccan higher education sector, which could be illustrative for other developing countries.
\end{abstract}

Keywords: Covid-19, Higher education, Scientific research, Distance Learning, Morocco.

\section{Introduction}

The development of the "knowledge economy" has given the university, as a key source of knowledge production and transmission, a fundamental role in the development of the economy. This role is reflected in the successive reforms that have affected this sector, both at the educational level and at the organizational and financial level to improve it. Since the beginning of the third millennium, the Moroccan university has undergone a wave of reforms to improve its quality and performance. The National Charter for Education and Training, the law 01-00 on the organization of higher education, and the License Master Doctorate (LMD) reform in 2003. In 2009, the State set up a State-University Emergency and Contracting program spread over four years which essentially aims to grant more and more leeway to the university for the effective exercise of their autonomy by giving more responsibility to the university and considering the State as the regulator, animator, and guarantor of national priorities. In 2015, the Higher Council for Education, Training and Scientific Research developed the 2015-2013 strategic vision, which will be the roadmap for the sector for the next 15 years. In response to this vision, the government promulgated in September 2019 the framework law No. 51.17 relating to the education, teaching, training, and scientific research which is the legislative basis of the vision. After the promulgating of the framework law, the ministry launched a pedagogical reform that replaced the LMD with the Bachelor system.

In January 2020, the world saw the spread of a new virus known as Covid-19. The impact of this virus has produced a pandemic that has spared no country. Faced with this situation, Morocco has launched a proactive strategy to limit the number of people infected by the virus since the beginning of March 2020. The government has declared a state of health emergency a halt in most activities, including the activities of universities. The lockdown has seriously 
affected the education system worldwide and influenced $87 \%$ of the world's student population and threatened their future education rights, according to the United Nations Education, Scientific and Cultural Organization (UNESCO). In Morocco, almost 10 million students were out of school because of the pandemic (El Firdoussi, Lachgar, Kabaili, Rochdi, Goujdami, and El Firdoussi, 2020). To ensure the continuity of the progression of the courses, the Moroccan Ministry of National Education, Vocational Training, Higher Education, and Scientific Research (MNEVTHESR) has launched a distance learning through TV Channels and asked universities to provide courses through Information Technology (IT) tools such as MOOCs, applications dedicated to e-learning or social networks.

This "sudden" change in strategy necessarily impacts all the components of the higher education sector. The purpose of this paper is to demonstrate the repercussions of this pandemic on the Moroccan higher education sector by presenting the negative effects and the opportunities offered by this pandemic to this sector.

This paper briefly presents the chronology of the pandemic in Morocco from the first case in China to the first case in Morocco in March 2020 and the actions launched by the government to avoid the spread of the pandemic. Then, it shows the evolution of the Moroccan higher education sector and the repercussions of the pandemic on this sector in terms of the process of learning, the research field, and the project of reforms. Finally, the article highlights the lessons learned from this pandemic for the Moroccan higher education sector and can be generalized to other developing countries.

\section{The Chronology of Covid-19 in Morocco}

The first case of Covid-19 was detected in China in December 2019. After three months, the virus has spared no country. Because of the rapid evolution of the international epidemiological situation, the World Health Organization declared that the coronavirus is a "Public Health Emergency of International Concern" on January 30, 2020, followed by a "pandemic" on March 12, 2020. Morocco detected the first case on March 2, 2020. The number of confirmed cases has gradually increased, which has led the government to close land, air, and sea borders since March 15, 2020. After the confirmation of 37 cases and one death, Morocco has chosen to replace face-to-face courses with distance courses for all school and university levels as part of a preventive strategy. A week later, Morocco established a gradual containment of the population. After the reducing of confinement, the State has chosen a decentralized approach to manage the crisis according to the epidemiological situation in each region. Thus, the movement between cities was conditioned by the agreement of the governor.

Since the spread of the virus, the state has mobilized its entire apparatus to deal with the coronavirus pandemic and provide it with an effective and transversal response to protect citizens. In terms of health, at the start of the pandemic, the head of government declared that Morocco currently has 640 resuscitation beds which is a low number for a population of over 45 million. As of November 11, Morocco had 2,676 intensive care beds. The number of intensive care beds has quadrupled, and in August 2020, the country made a $100 \%$ Moroccan resuscitation bed. The number of laboratories carrying out Covid tests has gradually evolved to include private laboratories in September 2020 after been limited to 2 public laboratories to alleviate the stress on public laboratories and ensure accessibility to all Moroccans.

In the lock-down period, the Moroccan health ministry has provided a transparent communication strategy through a daily Press release with the creation of an interactive digital portal dedicated to the developments of the new Coronavirus in Morocco from March 18, 2020. The government has also launched a Coronavirus exposure notification application "COVID-19" which must help notify and take care more quickly of people exposed to confirmed cases of COVID-19 and thus limit the circulation of the virus after the relief lockdown.

Facing the economic situation uncertain, King Mohammed VI ordered, on March 16, 2020, the creation of a special fund dedicated to the management of the coronavirus pandemic, which was endowed with 10 billion dirhams (934 million euros) to finance the cost of upgrading the 
medical device, in terms of suitable infrastructure and additional resources to be acquired, in an emergency. The Fund was supplied by the contribution of various private and public entities and redistributed as aid to households in a precarious situation and to businesses to cope with a possible recession (Driyef, Guillo and Badaoui, 2020). A monthly allowance was granted until the end of June 2020 for the benefit of employees declared to the National Social Security Fund, on temporary work stoppage, in companies in difficulty. To adjust macroeconomic imbalances, the country has also resorted to external financing.

The national vaccination campaign against the Covid- 19 virus, launched with great fanfare on January 28, 2021, by King Mohammed VI, reached 4 million people vaccinated in Morocco. According to World Health Organization, Morocco was among the top 10 countries to pass the vaccination challenge with, a percentage of $10,73 \%$ of the population vaccinated on 8 March 2021. Until 7 March 2021, Morocco recorded 485974 infected cases and reached 8676 deaths from the disease, while the recovered cases had reached 471919.

The first case of Covid-19 was detected in China in December 2019. After three months, the virus has spared no country. Because of the rapid evolution of the international epidemiological situation, the World Health Organization declared that the coronavirus is a "Public Health Emergency of International Concern" on January 30, 2020, followed by a "pandemic" on March 12, 2020. Morocco detected the first case on March 2, 2020. The number of confirmed cases has gradually increased which has led the government to close land, air, and sea borders since March 15, 2020. After confirming of 37 cases and one death, Morocco has chosen to replace face-to-face courses with distance courses for all school and university levels as part of a preventive strategy. A week later, Morocco established a gradual containment of the population. After reducing of confinement, the State has chosen a decentralized approach to manage the crisis according to the epidemiological situation in each region. Thus, the movement between cities was conditioned by the agreement of the governor.

Since the spread of the virus, the state has mobilized its entire apparatus to deal with the coronavirus pandemic and provide it with an active and transversal response to protect citizens. In terms of health, at the start of the pandemic, the head of government declared that Morocco currently has 640 resuscitation beds which is a low number for a population of over 45 million. As of November 11, Morocco had 2,676 intensive care beds. The number of intensive care beds has quadrupled, and in August 2020, the country made a $100 \%$ Moroccan resuscitation bed. The number of laboratories carrying out Covid tests has gradually evolved to include private laboratories in September 2020 after being limited to 2 public laboratories to alleviate the stress on public laboratories and ensure accessibility to all Moroccans.

In the period of lock-down, the Moroccan health ministry has provided a transparent communication strategy through a daily Press release with the creation of an interactive digital portal dedicated to the developments of the new Coronavirus in Morocco from March 18, 2020. The government has also launched a Coronavirus exposure notification application "COVID-19" which must help to notify and take care more quickly of people exposed to confirmed cases of COVID-19 and thus limit the circulation of the virus after the relief lockdown.

Facing the economic situation uncertain, King Mohammed VI ordered, on March 16, 2020, the creation of a special fund dedicated to the management of the coronavirus pandemic which was endowed with 10 billion dirhams (934 million euros) to finance the cost of upgrading the medical device, in terms of suitable infrastructure and additional resources to be acquired, in an emergency. The Fund was supplied by the contribution of various private and public entities is to be considered as a risk pooling mechanism and redistributed as an aid to households in a precarious situation and to businesses to cope with a possible recession (Driyef, Guillo and Badaoui, 2020). A monthly allowance was granted until the end of June 2020 for the benefit of employees declared to the National Social Security Fund, on temporary work stoppage, in companies in difficulty. To adjust macroeconomic balances, the country has also resorted to external financing. 
The King Mohammed VI launched national vaccination campaign against the Covid-19 virus with great fanfare on January 28, 2021. According to World Health Organization, Morocco was among the top 10 countries to pass the vaccination challenge with a percentage of $10,73 \%$ of the population vaccinated on 8 March 2021. Until 30 September 2021, Morocco recorded 933071 infected cases and reached 14267 deaths from the disease while the recovered cases had reached 906160 . The vaccination campaign reached more than 22 million people which is the half of the population.

\section{Research Methodology}

The researchers produce a comprehensive literature to carry out this review. The researchers identified the English and French publications which deal with the issue of the impact of covid19 on the Moroccan higher education sector and, that includes the following research: (Higher Education OR university OR enseignement supérieur OR université) AND (Covid-19 OR Coronavirus) AND (Morocc* OR Maroc*) in the Scopus database; Web of Science (WOS) and Google scholar. The researchers included papers published from March 2020 until the end of September 2021. They excluded articles that study special cases or high school students.

After collecting the articles, we performed a qualitative content analysis. The aim of data analyzes in qualitative approaches is "to provide knowledge and understanding of the phenomenon under study" (Downe-Wamboldt, 1992 in Mohuiddin et al., 2009). Thus, qualitative content analysis is a research method for the subjective interpretation of the content of texts through a systematic classification procedure, codification and, identification of themes (Hsieh and Shannon, 2005).

\section{Results and Discussion}

\subsection{Covid-19 and its Cmpact on the Process of Learning}

The choice of confinement has pushed the MNEVTHESR to put emergency plans to prevent education from being disrupted. Like most countries, distance learning (DL) has replaced learning face to face in Moroccan universities. Thus, five national TV channels rescheduled their programs to broadcast lessons for all school levels and undergraduate universities. Virtual classrooms via ZOOM or Google Meet, virtual Practical Work and, Social Networks (Facebook, youtube, WhatsApp) were also useful tools to communicate between teachers and their students (Ait Si Ahmad et al., 2021). In a statement addressed to university presidents, each university should provide its students with the learning resources (educational content) and technical support to enable them to study in good conditions. Thus, Moroccan universities have put the disposal of their teachers and students a platform to follow their courses via explanatory videos and course materials (Hibbi, Abdoun, and El Khatir, 2021).

\subsubsection{Distance Learning in Higher Education}

After the confinement, all universities practiced $D L$, exceptionally, instead of face-to-face education to guarantee the continuity of classes while ensuring the safety of students and professors. This sudden change certainly had an impact on the usual progress of lessons. Various studies have evaluated distance education in Moroccan universities during this crisis.

Table 1: Moroccan studies on distance education in the context of the pandemic

\begin{tabular}{|c|c|c|}
\hline Authors, year & Sample characteristics & Sample size $(n=)$ \\
\hline $\begin{array}{l}\text { Benkraache et al. } \\
(2020)\end{array}$ & $\begin{array}{lll}\begin{array}{l}\text { Moroccan } \\
\text { students }\end{array} & \text { teachers } & \text { and } \\
\end{array}$ & $\begin{array}{l}200 \text { Teachers } \\
1340 \text { Students }\end{array}$ \\
\hline $\begin{array}{l}\text { El Marhoum et al. ( } \\
\text { 2020) }\end{array}$ & Moroccan students & 3358 students \\
\hline $\begin{array}{l}\text { El Firdoussi et al. } \\
(2020)\end{array}$ & $\begin{array}{lll}\begin{array}{l}\text { Moroccan } \\
\text { students }\end{array} & \text { teachers } & \text { and } \\
\end{array}$ & $\begin{array}{l}231 \text { teachers } \\
3037 \text { students }\end{array}$ \\
\hline Rechidi et al. (2020) & $\begin{array}{lll}\begin{array}{l}\text { Moroccan } \\
\text { students }\end{array} & \text { teachers } & \text { and } \\
\end{array}$ & $\begin{array}{l}100 \text { teachers } \\
400 \text { students }\end{array}$ \\
\hline Hamdan (2021) & Moroccan students & undefined \\
\hline
\end{tabular}

This section presents the main results of these studies and the points of divergence and convergence between them. 


\subsubsection{Teacher's Perceptions of Distance Learning}

$\mathrm{DL}$ strategies can reduce the impact of the interruption of classic learning (Hbibi, Abdoun, and Elkhatir, 2021). $66 \%$ of teachers believe that the quality of DL is inferior to that of face-toface (Rechidi et al., 2020). A study by Benkraache et al. (2020) affirms these statements with $62 \%$ of teachers thinking that DL cannot replace face-to-face teaching even if $60 \%$ of these teachers feel adapted to this new type of teaching under these specific conditions. According to the same study, a third of these teachers are generally satisfied with their DL during a period of confinement. Thus, to improve the performance of this type of education, it is necessary to overcome the problems related to the Internet connection $(78 \%)$, to unify the methods of the DL $(71 \%)$, and to simplify the tools made available to teachers $(80 \%)$ (Benkraache et al., 2020; Rechidi et al., 2020). Finally, 64.5\% of teachers believe that the performance of DL largely depends on the performance of the institution concerned (Benkraache et al., 2020).

\subsubsection{Student's Perceptions of Distance Learning}

According to El Firdoussi et al. (2020), only $34.6 \%$ had taken a course online at least once before the lock-down. During the pandemic, $75 \%$ of students attended a video conference, while $80 \%$ enjoyed the experience (Louiz, 2020). Another study on a sample of 3,358 Moroccan students states that $83 \%$ took distance education during the lockdown period (EI Marhoum et al., 2020). Thus, $56 \%$ of students prefer recorded courses, while $15.95 \%$ prefer the materials to be downloaded (PDF, DOC, etc.) (El Firdoussi et al., 2020). 8 out of 10 students are little or not satisfied with DL during confinement (Benkraache et al., 2020), and $56 \%$ of students think the quality of DL is inferior to the traditional method (EI Marhoum et al., 2020). This disappointment is due to three main factors:

- An infrastructure unsuitable for DL: The quality of the Internet network turns out to be the main obstacle blocking the success of IT. Nearly $80 \%$ of the people questioned declare having connection problems that block their work, mainly when using tools requiring direct and instantaneous interaction (Rechdi et al., 2020). The results show that $57.38 \%$ of students are not satisfied with the network and internet access (Hantem et al., 2020). While at the means used to take the courses remotely: $15.66 \%$ said they took the courses from a smartphone (EI Firdoussi et al., 2020).

- A lack of supervision: following the state of emergency which imposed this new teaching method, the results of studies have shown a lack of supervision during confinement. Only $8.3 \%$ of the students surveyed declared that they were up to date in their courses, against around $60 \%$ who were generally late. $28.4 \%$ of students cannot organize themselves and are very late (Benkraache et al., 2020). Besides, only $40 \%$ of students said they were supported by their institutions in DL (El Merhoum et al., 2020). 95\% of the students emphasized their desire to benefit from support on distance learning platforms (Hamdan, 2021).

- A critical psychological situation: according to a survey by the World Health Organization: "Covid-19 can cause neurological and psychiatric complications (confusional state, agitation or stroke, for example)". Hantem et al. (2020) affirm these comments with their study, which shows that $83 \%$ of the students surveyed are worried about the pandemic, which impacts negatively their concentration level and increases their level of stress about their exams.

As a result of this dissatisfaction, more than $70 \%$ had a negative impression of the DL during confinement, and $57 \%$ were not ready to take DL courses in the future (Benkraache et al., 2020). However, $97.5 \%$ of students display motivation for distance learning in the coming years because of the promising future of this type of learning

\subsubsection{Disruption of the Academic Calendar}

At the beginning of the pandemic, the MNEVTHESR in Morocco has categorically denied having announced "a blank year" for all school levels. The solution was to ensure a DL process and the academic calendar will depend on the "epidemiological situation" and the "conditions for lifting the lock-down". Then, the spring session's exams of the 2019-2020 academic year were reported to the beginning of September 2020, and the start of the 2020-2021 academic year was in mid-October. (Hibbi et al.,2021). 
At the end of August 2020, The department of higher education has announced that students would have the possibility of choosing between distance or face-to-face learning in a small group. The same source declares that the pedagogical model adopted could at any time be adapted at the level of each higher education establishment, depending on the evolution of the epidemiological situation and changes that may occur in each region (Hibbi et al., 2021). As for the modalities of the 2020-2021 academic year, the ministry stressed that the preregistration of new students was initiated remotely via the electronic platforms of the universities. According to a schedule announced by each university separately, face-to-face teaching will be accompanied by a set of preventive measures, in full coordination with the competent public authorities, to strengthen prevention and health security, focusing mainly on the compulsory wearing of masks inside university spaces, the reduction of the number of people in the amphitheaters and the classrooms, as well as the disinfection of the training and teaching spaces continuously. As a result, each establishment followed its learning strategy and examination method according to the epidemic situation of the region and according to the number of students.

\subsubsection{The Cancellation of Recruitments and Promotions of Professors}

It was expected that the government would come to put in place austerity measures to preserve the budget of State government because of this unprecedented crisis. The first measure was the postponement of promotions and the cancellation of recruitment competitions in the public administration on March 25, 2020. The administrations responsible for internal security and health were excluded from this measure.

The national education federation, therefore, refuses any freeze on employment in the public education sector, stressing that "Morocco needs free, unified and solid public education to face the devastation, disasters and future challenges with generations of researchers, scientists, doctors, experts, producers, and creators, while recruitment continues to reinforce a securitybased approach, which is a sign of the failure of government public policies." Therefore, recruitment offers for professors were relaunched before the end of 2020.

\subsection{Covid-19 and its Impact on Scientific Research}

The Scientifics research was among the sectors which were highlighted during the pandemic and which recorded important performances during this crisis.

\subsubsection{Access to E-resources}

Under the confinement conditions, several publishers and service providers have offered extended access to their resources free of charge for a fixed period to facilitate researchers' access to scientific resources. These initiatives aim to help the academic world, researchers, and the general population to have the information they need at these particular times. The purpose of this initiative is to support global research efforts to understand, diagnose and find a cure for this pandemic. According to the National Center for Scientific and Technical Research (NCSTR), 70\% of publications on the new virus have been freely accessible on the Scopus databases to facilitate research on the Coronavirus.

Moroccan researchers have also benefited from this initiative through the electronic resources of the Moroccan Institute of Scientific and Technical Information. Expanding access to electronic resources is one of the opportunities this pandemic has presented to researchers.

\subsubsection{Calls for Scientific Research Projects}

One of the "benefits" of Covid-19 is the promotion of scientific research. This pandemic has highlighted the important role played by research in emerging from the crisis. In this context, several calls for scientific research projects have been launched. In April 2020, the Department of Higher Education and Scientific Research, as well as the NCSTR set up a multidisciplinary research support program in areas related to the current pandemic. With a budget of 1.111.325,00 Dollars, the department aims to develop solutions that will contribute to the management of pandemic crises based on the research results.

The "Agence Universitaire de la Francophonie" (AUF) has also launched an international call for projects to support university initiatives related to Covid-19. With one million euros, the AUF selected 92 projects, including 4 Moroccans.

\subsubsection{Scientific Publications}


All statistics based on bibliographic data from publishing houses show the unprecedented pace of scientific publications related to Sars Cov 2. Given the maon health emergency caused by the virus, more than 4000 articles and communications from all kinds on Covid-19 were listed on PubMed between January and the end of April 2020. By comparison, it would have taken 24 months to reach the same number of articles during the 2009 H1N1 influenza pandemic (Sarkis, Assaf, and Sarkis, 2020). According to the NCSTR monitoring service, nearly 14,192 patent applications related to the coronavirus family (SARS and MERS) were identified between 2000 and 2020. The first three months of 2020 have already recorded 28 applications.

All these publications have sparked more collaboration between different countries to face this unprecedented global health crisis. These collaborations generated more than 114075 contributions treating Covid-19 in all aspects published on the Scopus network until March 2021 and 90399 publications indexed in WOS. The NCSTR published a bibliometric study on Covid-19, which showed that as of May 28, 2020, Moroccan researchers had accumulated 21 scientific publications, indexed in the Scopus database, and 32 at the level of WOS.

\subsection{Covid-19 and its Impact on Current Projects}

The pandemic had an immediate influence on all the projects that were initiated by the higher education department. Many projects were delayed because of the pandemic; this article presents three big projects of the higher education department that have experienced delays due to the pandemic.

\subsubsection{Bachelor Reform}

After 17 years of the LMD system (license degree in 3 years, Master's degree in 2 years, and Doctorate in 3 years), Moroccan universities will switch their educational curriculum to the Bachelor model, which replaces the license for four years. The objective of this new system is to improve the graduation rate at the bachelor's level and the professional integration rate of graduates by emphasizing the new system on soft skills. As part of this project, it was planned that the universities set the content of the various training courses before March 31, 2020, and that its application will be effective from the next school year, scheduled for September 7 , 2020. The Covid-19 has upset the ministry strategies. In these exceptional conditions, the concern of the ministry has become the adaptation of the university to the health crisis to reduce the maximum number of cases infected with Sars-Cov 2 and save the academic year 2020/2021. The Bachelor was postponed until the next school year to be deployed according to a "progressive experimental" approach.

\subsubsection{Auditum Project}

In cooperation with the European Union's Erasmus + program, 6 Moroccan universities have been applying the "Auditum" project since January 2018, which aims to strengthen governance in Moroccan universities by setting up an audit and internal control function allowing the verification of the efficiency in the performance of the university's missions, the assessment of the physical and accounting sincerity of the operations, the judgment of the 'efficiency of the accounting and financial information system and suggestions for improvements. This function should ensure, depending on the project site: "compliance with the application of financial and accounting management rules and procedures, compliance of profiles with skills needs and optimal use of Information Systems by the implementing of the procedural prerequisites necessary for the correct use of these systems.". This project is spread over two years (from 2018 to 2020) to prepare all the documents necessary for the successful establishment of an audit and internal control function within Moroccan universities (a legal framework and organizational structure common to all Moroccan universities, put in place Moroccan university management procedures manual, a quality plan, etc.).

It has been programmed under normal conditions to prepare all the documents necessary to implement an audit and internal control function within Moroccan universities at the end of 2020. Since March 2020, project activities have been postponed to a later date following the pandemic caused by Covid-19.

\subsubsection{The University Organization Certification Project}


Moroccan universities do not have an organizational chart approved by the Ministry of Higher Education and endorsed by the Ministry of Finance. Existing organizational charts are functional organizational charts that change from one academic institution to another. Universities have found several failings due to the lack of a certified organization chart which does not allow universities to formally appoint positions of responsibility. Indeed, the absence of an organization chart slows down the reissuing operation the accounts due to the lack of accountability means. Also, the supervisory ministry noted a significant turnover at the level of designated "managers", which leads to a growing demotivation of executives for "positions of responsibility". This situation negatively influenced administrative and financial performance due to the limited visibility of responsibilities and functions.

In January 2020, the Department of Higher Education launched a University Organizational Chart Certification Project with the Ministry of Finance and cooperated with the Conference of University Presidents. This project concerns the Presidency, institutions, and common services at the university. The proposed organization chart will be unified and vary according to the number of students at each institution. Thus, the project divides the presidency into 5 poles, 8 divisions, and 19 services. The certification project was postponed like all other university reforms because of the exceptional health situation.

\subsection{What Lessons can Universities Learn from this Pandemic?}

After one year of the outbreak of this health crisis, several lessons can be learned for Moroccan universities and university' developing countries.

\subsubsection{Importance of Information and Communication Technologies for Education}

After the pandemic, no one can doubt the importance of integrating information and communication technologies for education (ICT) in worldwide universities. They are moving increasingly towards online learning or E-Learning. Higher education responsible must double its efforts to develop ICT resources within its universities. The MUN (Maroc Université Numérique) platform allows Moroccan universities to develop MOOCs (massively open online courses), SPOCs (online courses in small private groups), or any other form of online course must enrich its content to play its role fully under similar conditions. The State should relaunch programs to generalize computer and internet connexion to all students and professors. Training in e-learning techniques for the benefit of teachers and students is also an essential element to ensure the proper functioning of the learning process within universities.

\subsubsection{Massification: A Handicap for the Performance of Moroccan Universities}

Since the 1990s, massification has been a major issue for the Moroccan university harming its performance. Contrary to what massification may claim, it is neither the meaning of the extension of the offer of higher education, the success of a greater number of students, nor the attractiveness of university. Massification in Morocco depends directly on financial allocations from the State. Indeed, the state is the main provider of funds to universities. This effort has been sustained and, the credits allocated to higher university education have increased significantly since the 2003 reform, particularly between 2009 and 2017. It has risen from 7.5 billion dirhams to more than 10 billion dirhams. However, the increase in student numbers has outweighed these budgets. Thus, the percentage of the budget allocated to university higher education concerning (GDP) remains below $1 \%$ throughout this period. In addition, the operating budget of the Ministry of Higher Education fell between 2012 and 2017 following the decrease in the wage bill. This decrease is due to the non-replacement of all retirements and the strategy of redeploying civil servants with doctorate to assistant professor positions. The state must therefore review its faculty recruitment policy to win the bet on the performance of its higher education sector.

\subsubsection{Scientific Research as an Engine of Growth and Development}

One of the benefits of this pandemic is the revaluation of scientific research. During the crisis, scientific researchers have become the "new stars" of the world and, everyone is eagerly awaiting their discoveries.

Morocco must understand that scientific research is the basis of all nations in the era of the knowledge economy. To develop this strategic sector, the government should first increase 
the funds allocated to research and development, which reached $0.8 \%$ of GDP in 2019 . This low rate compared to the OECD average of $2,3 \%$, will not allow Morocco to find its place with the developed countries.

\subsubsection{Development of Internal Management in Universities}

The health crisis has revealed the important role played by university officials in managing risks. These managers are required to use modern managerial tools more than ever. Universities must modernize their management method through the establishment of a system of Audit, management control, internal control, and efficient information system to be able to face such a crisis and not fall into the trap of delaying projects and courses, which therefore influence the performance of universities.

Indeed, an effective management information and control system will enable universities to carry out the tasks entrusted to operational management and, therefore will help in decisionmaking. The implications of IT tools in terms of performance management are at different levels. For Daft (1992), IT tools allow both operational efficiency and efficiency in management processes and also contribute to the strategic effectiveness of the management control function. IT tools can thus contribute to the development of interactive control (Simons, 1990) because they provide an inventory of key indicators in real-time and thus facilitate communication between the strategic summit and the operational managers who feed the database Management (Boitier, 2002). Finally, establishing an audit and internal control function will ensure the efficiency of management processes and minimize risks.

\section{Conclusion}

2020 was a year like no other following the spread of the coronavirus. COVID-19 is the global crisis of our time, which has affected the lives of more than 7 billion people, and is the biggest challenge we have faced since World War II. Morocco has followed a proactive strategy to fight the virus. At the pandemic start, Moroccans expressed their satisfaction with the united soul that was present at the pandemic beginning (Driyef, Guillo, and Badaoui, 2020). But the pandemic is much more than a health crisis, it is also an unprecedented socio-economic crisis that has had social, economic, and political impacts that will leave deep scars that will be slow to fade. The higher education sector has been disrupted following university closures during the lockdown period. Developing countries are the most affected by the health crisis because of their deficiency of health and education systems. Overall, the Moroccan higher education sector was negatively impacted during the pandemic. Its learning mission was negatively impacted the most, while the scientific research mission saw improvements in publications and research funding during the crisis. To maintain an optimal level of performance, the university must upgrade its technological infrastructure and provide training for teachers while acquiring new management tools. The pandemic paved the way for a new hybrid education model were, on the one hand, the integration of ICT and the introduction of an e-learning culture and practices (Benseddik, 2020). This study would help higher education institutions and ministries in developing counties to compare the impact of covid-19 on the higher education sector and to deal with any eventual health crisis

\section{References}

- Ahmad, H., El Kharki, K., \& Berrada, K. (2020, September). The agility of the Post COVID-19 Strategic Plan on Distance Learning at Cadi Ayyad University. An Opportunity Towards a Total Digital Transformation of the University. In International Workshop on Higher Education Learning Methodologies and Technologies Online (pp. 199-213). Springer, Cham. https://doi.org/10.1007/978-3-030-67435-9_16 CrossRef

- Benkaraache,T., Benabdelouahed R., Belafhaili M., Dafir A., Nafzaoui A. et EL Marhoum A. (2020). Continuité pédagogique et enseignement à distance en période de confinement : Perception et satisfaction des acteurs universitaires. Enquête nationale auprès des étudiants et des enseignants universitaires-Mai2020.

- Benseddik, M. (2020). L'université marocaine à l'épreuve du Covid-19. AEGIS, 37. 
Belhassan Khaoula, Azegagh Jalal

The Impact of Covid-19 on Higher Education: A Review on the Moroccan Case

- Boitier, M. (2002). L'Influence Des Technologies De L'Information Et De La Communication Sur La Fonction Controle De Gestion. Une Analyse Socio-Technique.

- Centre National de la recherche scientifique et technologique (2020). Covid-19 dans les bases de données scientifiques. Service Veille Scientifique et Technologique. Worksheet avril 2020. Maroc.

- Daft, R. L. (1992). Organization theory and design, St. Paul, MN: West Publishing Company.

- Driyef M., Guillo D. et Badaoui S. (2020). Le Maroc face à la pandémie Covid-19 : de la confiance à l'inquiétude. Policy Center for the New South.

- El Firdoussi, S., Lachgar, M., Kabaili, H., Rochdi, A., Goujdami, D., \& El Firdoussi, L. (2020). Assessing Distance Learning in Higher Education during the COVID-19 Pandemic. Education Research 2020. https://doi.org/10.1155/2020/8890633 CrossRef

- El Marhoum, A., Ezzahid, E., \& Zouiri, L. (2020). L'enseignement à distance au Maroc : perceptions des étudiants en période du confinement Covid-19 à partir d'une enquête nationale.

- HAMDAN, Y. (2021). L'évaluation de l'enseignement à distance par les étudiants dans les universités marocaines au temps du COVID-19: Expériences et perspectives. Revue Marocaine de I'Évaluation et de la Recherche Educative, (5), 456-478.

- Hantem, A., (2020). Les conditions de l'enseignement à distance pendant le confinement dû au COVID19 : Cas de l'enseignement supérieur au Maroc.

- Hibbi, F. Z., Abdoun, O., \& El Khatir, H. (2021). Coronavirus Pandemic in Morocco: Measuring the Impact of Containment and Improving the Learning Process in Higher Education. International Journal of Information and Education Technology, 11(1), 30-4. CrossRef

- Hsieh, H. F., \& Shannon, S. E. (2005). Three approaches to qualitative content analysis. Qualitative health research, 15(9), 1277-1288. CrossRef

- Louiz, D. (2020). Enseigner à distance au temps du Covid-19, cas de la Faculté des Lettres et des Sciences Humaines Ibn Tofail de Kénitra. Didactique, sciences cognitives et littérature. P 96-113.

- Mohiuddin, M., Mbibi, S. M. A., \& Al-Azad, S. (2009). Étude qualitative de l'impact de la gestion de la diversité culturelle sur l'avantage compétitif des entreprises. Journal of Global Business Administration, 1(1).

- Organization Mondiale de la Santé (2020). Selon une enquête de l'OMS, la COVID-19 perturbe les services de santé mentale dans la plupart des pays. Communiqué de presse. Consulté sur : https://www.who.int/fr/news/item/05-10-2020-covid-19disrupting-mental-health-services-in-most-countries-whosurvey\# : : text=Beaucoup $\% 20$ de $\% 20$ gens $\% 20$ consomment $\% 20$ plus, vasculaire $\% 20 c \%$ C3\%A9r\%C3\%A9bral\%2C\%20par\%20exemple).

- Rechidi, N., Bennani, H., Nafzaoui, M. A., \& Benazzou, L. (2020). L'intégration pédagogique des TIC à l'épreuve de la crise covid-19 : Quels enseignements à tirer?. Revue internationale du chercheur vol $1 \mathrm{~N}^{\circ} 2$.

- Sarkis, J., Assaf, J., \& Sarkis, P. (2020). Publications durant la pandémie du COVID-19 : entre quantité et qualité. La Presse Médicale Formation. $\underline{\text { CrossRef }}$ 